Review article

UDC: 394/395(450)"14"

ID: 228296716

DOI 10.25106/AHM.2016.1212

\footnotetext{
Angelina Milosavljević-Ault

Faculty of Media and Communications

Karađorđeva 65, 11000 Belgrade, Serbia

E-mail: andjelijam@gmail.com
}

\title{
FROM PRECEPT TO REGULATION OF RENAISSANCE HOUSEHOLD: LEON BATTISTA ALBERTI'S “DELLA FAMIGLIA AND ANONYMOUS’ ORDINE ET OFFICIJ DE CASA DE LO ILLUSTRISSIMO SIGNOR DUCA D' URBINO”*
}

\begin{abstract}
Precepts for the conduct of individuals at Renaissance courts and in urban settings still offer plethora of information about the gradual codification of the life styles of the elite, written as statutes used in closed court settings, or as widely read treatises. Such is the case with two $15^{\text {th }}$ century manuscripts: a copy of the regulation of the life at the Montefeltro court, Ordine et officij de casa de lo Illustrissimo Signor Duca d' Urbino (Cod. Urb. lat. 1248, Biblioteca Apostolica Vaticana), and Alberti's De Famiglia. Both authors strove to establish models for ideal court and civic households, respectively. They certainly represent already established practices, dealing with everyday duties and obligations of masters and servants. In this paper, we are representing several issues that pertain to both court and civic settings.
\end{abstract}

Key words: household

Non MeSH: Renaissance, Ordine et Officij, Federico da Montefeltro, Della Famiglia, Leon Battista Alberti

Historical writings feature an interest in the ordinary life of the past and archival documents still harbor plethora of information that has been researched in the contexts of power, wealth, patronage, social and economic issues, gender studies, and similar. The interest in $15^{\text {th }}$ century Italy derives not only from the culture of the Renaissance as the cradle of the modern age, but also from the boundless wealth of

* This paper is realized on the research project Modernization of the Western Balkans, OI 177009, financed by Ministry of Education, Science and Technological Development of The Republic of Serbia. 
documentation, both literary and statistical, which allows us to gain a deeper understanding of the Italian life styles that still inform so much of our own culture. The epistolary sources, account books, and religious literature offer vivid images of Renaissance households and their everyday concerns. The courts of Italy remain of vital significance in every assessment of Renaissance history and culture, and are still subject to scrutiny.

The court of Urbino counts as one of the most studied Renaissance courts, especially in terms of art patronage, and of cultural and political strivings of one of the most famous Renaissance lords, Duke Federico da Montefeltro (1422-1482) [1, $2,3,4,5,6]$. The palace of Urbino has, also, often been associated with Castiglione's elegant evocation of the milieu in which he resided during his youth, in his famous Book of the Courtier (1528) whose dialogues took place in exactly this setting characterized as the place of birth of European aristocratic culture. It was followed by a series of treatises on the conduct of courtiers, such as the famous Galateo by Giovanni della Casa (1558), but the precepts for the conduct of individuals associated with courts are certainly of a much older date. One of them is Hincmar de Rheims' De Ordine Palatii. Although written by an ecclesiast, it features the concern with king's virtuosity and religiousness, but also the statement that proper organization of palace is necessary to suit good government (le palais du roi était organisé comme il suit, pour le bien du governement tout entier) [7, esp. p. 35]. However, it is due either to their often fragmentary nature or narrow local importance that such documents have often been overlooked by scholars as important instances in the codification of court life even in the Renaissance with its flowering new secular culture, when court was still basically a household in service of a lord. This is the case with still understudied document titled Ordine et officij de casa de lo Illustrissimo Signor duca de Urbino (Cod. Urb. lat. 1248, Biblioteca Apostolica Vaticana) [8]. Its value and importance lie in the wealth of information that renders clear image of the Montefeltro's household (the famiglia) as machinery that operated behind the display of the seigniorial nobility of the Duke, who most probably modeled his court after older Italian courts, such as the Visconti/Sforza's, or the Gonzaga's, or some other noble family [9]. Hence its importance for understanding of the Renaissance court practices, not necessarily as a model, but mainly as a record offering deeper insight into its everyday concerns. We are taking household as main paradigm, because the Ordini reflect what in the eulogic and apologetic literature of his day featured as one of the most prominent Federico da Montefeltro's characteristics as the father of state, and true patron and provider for his people and court, in which there existed a perfect order held under his magnificent supervision [10,11]. Writing about Federico's domestic concerns, Vespasiano informs us that he "daily distributed at his palace a considerable amount of bread and wine", that he regarded his subjects "his children, and was at all times accessible to hear them personally state their petitions", and that he administered the running of the state and court in such way that he "brought it entirely under control". [10, pp. 401-408] 
Understanding of the Montefeltro household, and the life of the Renaissance seigniorial courts in general, cannot be fully achieved without documents such as the one we are addressing here, concerning the everyday life behind the scene of the court etiquette and its offices and their duties, such as librarian, chancery, master of guardaroba, treasurer (we touched upon these offices briefly in discussing Federico's studiolo in Urbino [2, pp. $43 \mathrm{ff}$ ]]), or cooks, pages, and ordinary servants.

During $15^{\text {th }}$ century, it was not unusual for a prince to get personally involved with the details of running a household and a court (from building to engineering, to choosing cloth and decorations for festivities, and similar) [12], and we know that Federico da Montefeltro perceived his palace in Urbino as a fitting and lasting memorial to himself and to his ancestors. So he took an active role in building of fortifications, administration of the state, in taking care of the poor and needy, and such, "having decided to make in our city of Urbino a fine and worthy habitation commensurate with our own condition..." $[1,3,6,13]$. He also created a large household (famiglia), which rose to the total of 317 members (actually, 355 with the addition of the Duchess') in the Duke's service, in 1482, with strict stratification and hierarchy [14]. Let us remind that the famiglia (family, household) and corte (court) were often used as synonyms; both represented, it should be noted, the nucleus, the core, of the system of government in aristocratic, noble, settings, as much as of the entrepreneurial families in the Renaissance republican states, such as Florence and Venice $[15,16,17,18]$. Naturally, corte also referred to architecture, and famiglia often specifically referred to the immediate nuclear family. However, we are here concerned with the, so called, extended family of servants affiliated to the court with strong personal relationship with the lord. We assume that the establishment of household operated according to a tradition, and that its codification and standardization coincided with the need to organize, more or less public, life at European courts, and with the rising awareness that the whole domestic setting, architectural as well [17, Book V], conveys an image of the ruler (as a pater famillias) through strict honoring of a decorum (actually, in seigniorial settings as well as in urban entrepreneurial settings of wealthy citizens). The nature of these affiliations varied, and some them were very formal, linking people up and down the social hierarchy, as mutually dependent members of extended families. These were complex communities characteristic among the upper ranks of society, whether seigniorial or entrepreneurial $[15,16,19,20]$, and this is reflected in the contents of two documents we would like to look at in this paper, that contain advices on management of domestic affairs. We see them as reflections of the $15^{\text {th }}$ century tradition, regardless of differences in their literary qualities and in personal/ official interests/duties of their respective authors. These are the Florentine humanist Leon Battista Alberti's (1404-1472) Libro della Familia, written around 1444, and Ordine et officij de casa de lo Illustrissimo Signor duca de Urbino, written by an anonymous Urbinate, who apparently served as maestro di casa, and recently attributed to Pietro Tiranni of Cagli $[8,16]$. Alberti and Tiranni wrote these documents, one as a treatise in the form of dialogue, and the other in the rigid form of statute. They, also, 
definitely wrote them from different social perspectives: one from the republican, civic, and entrepreneurial viewpoint, the other from the perspective of a court administrator (in essence, a servant himself), who was to supervise the Urbinate court etiquette and decorum. Both document, however, an established tradition of running a household - to serve the honor of the master - and they represent sources of inquiry revealing of many facets that we cannot address in this preliminary research. We would like to suggest to look at them as reflections of existing tradition in administration and ordering of everyday life in the $15^{\text {th }}$ century Italy, designed to ensure efficiency and smooth operation of households, while a new, more aristocratic, trend in which servants gradually became objects of display and necessary accouterments of the noble style of life was a product of the culture of the $16^{\text {th }}$ century $[15,21$, 22]. We would like to address the Ordine et officij de casa de lo Illustrissimo Signor duca de Urbino first, as it was this particular document that served as inspiration for this essay, and in which we recognized the similarities with Alberti's treatise written slightly before, and that has mostly attracted scholars interested in Alberti's writings on ethics $[16,23]$.

\section{Ordine et officij of a Duke}

The lost document of the Ordine et officij de casa de lo Illustrissimo Signor Duca d' Urbino, written most probably at the end of the $15^{\text {th }}$ century, is preserved as a (fragmentary) manuscript copy, which was edited and published by Sabine Eiche in 1999 [9]. The identity of the original author of the Ordine et officij in still unknown, but it is now attributed to Pietro Tiranni da Cagli, who served under the house of Montefeltro, and later on under the della Rovere. Sabine Eiche and John Easton Law, who focused on the contribution of this treatise to the study of the court, state that the document was written after Federico's death (1482), although they affirm that there is no specific reference to his heir, Guidobaldo I (1472-1508), either [9, pp. 15-18; $24]$. We would only suggest here that the document was actually written before, for the purposes of Federico da Montefeltro's household, and copied later on, trusting that future research may prove this to be the case, as does the fact that his large household, mentioned above, was comprised of exactly the same offices described in the Ordine. Be it as it may, let us note that judging by the tone and the address of the very document, its writer served as maestro de casa, the person who played the crucial role in the life of Renaissance signore, in charge of the supervising of the whole household. That the writer was well introduced into the subject is evident by his statement that he wrote the Ordine after fifty-years-long service as a courtier [9], and that he knew was acquainted with the courts of the Visconti/Sforza in Milan and pope Pius II in Rome. The importance of these families for Federico can never be accentuated enough. Namely, many personal honors bestowed on Federico came from these noble potentates, as in 1460 he married Battista Sforza, and received the title of the general of Italian League from the Pope Pius II, who granted the hereditary right 
of his male descendants to territories Federico conquers [6, pp. 31-33, with up-todate bibliography]. So, it should not come as a surprise that he chose these models to organize his own court in Urbino, and the rigidity with which he organized his household, noted in Vespasiano's account: "His household was regulated much in the manner of a religious establishment and the five hundred mouths which it contained lived with almost monastic regularity. There were no mess-table manners there; no gambling not blasphemous language and all expressed themselves with the utmost moderation." [10, p. 360] The rigidity of the text of the Ordine reflects clearly the brief, but vivid, Vespasiano's account.

The Ordini were written in statutory form, as a document for the internal use, with comfort, health and prestige of the lord as main concerns of the members of the household, and with a great sense of mutual obligation and concern of all them, including the lord himself. They were to be ensured by strict stratification of the offices, from those in the direct service of the lord, who were the closest to his "body", such as cameriero magiore, to those who had little or no direct contact with him, such as mulatori. The physical contact with the lord directs further stratification of the offices from the lower (servants) to the higher ones (cancellaria), to give a sense of the life at a well regulated court. The writer of the Ordine, who took his task as the maestro di casa to regulate and supervise everyone's roles in this stratified community seriously, stipulates that it is necessary, that the lord gives audiences every day, or at least three times a week, to "the maestro de casa, the seneschal, the chief archivist and the chief treasurer, at the hour which pleases him the most, and to be available to the vicar and to his secretariat all times". These were the ones to report any disorder to the lord, and he was the only one to take measures against any offence, as the true pater famillias. [8, Cap. LXIIII]

Maestro de casa was to manage the everyday life at court and he was also supposed, it seems, to instruct in morals and manners the servants and officials who were to do everything with virtue (virtù), grace, dexterity and modesty (gratia et modesta maniera; dextreza et maniera). They were, also, to present themselves as gallant, in good spirits, well spoken and graceful (gallanti, allegri in festa et acostumati cusì in parole commo in gesti per modo che gli ha a vedere sia constrecto ad amarli et laudarli) [8, Cap. III, V, XI]. The centrality of the figure of the Duke is clearly accentuated in the opening words of the Ordine: it is necessary to serve the lord with diligence and in observation of the regulations (Cap. I). It was the maestro de casa's duty to see that the Duke's will is done in proper and decorous way, modestly, justly, and to act with authority, in accordance with the Ordini (Cap. II). That the palace was a very closed setting, indeed, and in it servants a special type of employees, the already mentioned members of the extended family is clear from the tone and the stipulations of the document, which also imply the notion of mutual obligation: the lord was to feed and dress, and provide for the whole famiglia, treating the servants not as servants, but as relatives who wish to maintain and lead their master to honorable end (non commo 
servi ma como congiunti, volendo fare el signore l'honore suo a mantenerli et condurli a fine honorato, Cap. XXVI, and also Cap. XXIV and XXV).

One of the main concerns of the writer of the Ordine is cleanliness. The document is replete with references to hygiene, personal and general: the lord is to be served (breakfast and dinner) tasty dishes he likes and with splendour, and - above all - cleanliness (signore sia servito secundo el suo gusto e spledidament et sopra tucto polito, Cap. III). Should somebody smell badly (tristo odore) due to a "natural defect", they should treat the disease with diligence and under medical supervision. Everybody was to wash themselves often (lavarse speso), their feet so that they don't smell badly, and no unclean parts of the body are to be touched, as everybody's hands were to be clean (sopra tucto ... da tenere polite le mano, Cap. III). The concentration on the cleanliness has many implications, naturally, but it leads us to believe that the Ordine was initially written for Federico da Montefeltro's court, especially if take into account that he suffered a grave infection in his early youth [11], and was obsessed, throughout his life, with cleanliness of food, dishes, clothes, as much as of hands, nails and faces, everything without slightest suspicion of dirt (e tucto senza uno minimo suspecto de immunditia, Cap. XXXV). This attitude to dirt in domestic space is certainly related tothe ancient understandings of the human body and the origins of diseases. Combined with such matters as the routine of meals and their menus in summer and winter, table furniture for the Duke and servants, the clothing given to the household members, and similar, are the material from which we may come to an imaginative, fuller reconstruction of the life in the palace (which we shall touch upon, hopefully, on another occasion). Domestic dirt is a "little-examined yet always present axis of social organization", as Nadine Monem noted, and notions of what constituted dirt or cleanliness directly and indirectly influenced the arrangement and use of all interior and exterior spaces, and what is clean, or dirty, is defined by social contexts [26, p. 38], individual or communal, let us add.

\section{Household in an Urban Setting, Della Famiglia}

Books on family life, actually, mostly instructions for virtuous conduct of men and women, were not unknown during the Middle Ages and the Renaissance [25]. One of the most famous is Leon Battista Alberti's I Libri Della famiglia, written in 1444 in the form of a dialogue, first published only in $18^{\text {th }}$ century, but widely read in manuscript copies [16] in which he deals with the daily life of a family, notably one living in urban setting, such as Florence. Alberti, like the most of the authors of such treatises that were concerned more with the behaviour of higher classes than with servants and households, was mostly concerned with prescribing good and virtuous husbandry, as it is the very essence of good living in a well ordered civic society. However, daily life of a good husband of a family has much to do with practical matters, which he did not altogether dismiss from his writing, and he addressed these matters (albeit not in great detail), in the Book Three of the Della famiglia. The Book 
Three of the Family is about prudent management of a household. It covers topics of management of goods, children, women and servants. Alberti, let us remind, never married or ran a business, nor did he reside for long in Florence. He was a courtier, an artist, an official active in various republics and principalities, and was a prolific writer who offered many precepts, systems of management, for various human activities (just to remember his important Della Pittura, 1435), embodied in his sentence from the Della Famiglia, "we should have order and system in all that we do." [16, p. 96] For Alberti virtue (virtu) is linked to aesthetic goals such as balance and harmony, as well as to ethical interaction within a peaceful and efficient hierarchical system. [16, p. 10]

Good husband/father governs his family well because he wants the glory of his name to shine and to last - similar to any Renaissance lord in his court setting. By family Alberti means children, wife, and other members of the household, both relatives and servants [16, p. 50], and he makes sure that wife and children and servants perform their functions well, because he makes it clear that their own advantage depends on following his guidance. He not only has the power to withdraw his support if they do not obey, but he has the wisdom to see that everyone does what he or she is naturally best at doing. And one is to "apply a system of good management" to them by employing them in honorable ways, giving them virtuous and valuable tasks, keeping them healthy and contented, and seeing that "no one wastes his time" [16, pp. 50-51], and they should, in turn, preserve and use the family's property with care. The father of the family should be omnipresent, and he needs to keep everything in check, although he leads a public life [16, p. 50]. Needing help with the household while attending to regular business, the only person he might consider putting his trust in is his wife. The mistress should take care of the household, preside over it with modesty, serenity, tranquility and peace, seeing that nothing goes wrong $[16, \mathrm{p}$. 81]. And the father of the family, the husband, is to teach his wife the management of the household [16, p. 88], as her job would be, just like his, to give everyone some suitable work to do, and keep an eye on everyone and everything. The keys to various rooms in the house should be in the custody of the mistress of the house. Only keys used every day, like the pantry and storeroom keys, should be put into the keeping of "one of the best servants, the most loyal and honest, the most trained and scrupulous and conscientious about our property" [94]. Addressing the wife further, Alberti, or rather one of the interlocutors (who spoke Alberti's mind), Giannozzo, instructs her, "Also see that the man you put in charge of the other servants gives all of them enough so that they are spared hunger and thirst. If they lack necessities, they will serve us poorly and not give zealous care of our concerns. To healthy servants you will see that good things are given, so that none of them grows ill; for those who are not healthy you must arrange a proper diet and take good care to restore them to health. It is mere thrift to cure them quickly, for while they lie ill you can get no service from them and all you have is the cost of maintenance. When they are healthy 
and free, they will serve you all the more faithfully and devotedly. Thus, my dear wife, you should see that everyone in the house has what he needs." [16, p. 94].

Servants differ in their rank in urban settings as well, and should dress according to their station, but well, "If I neglect to do this, my flock would give me but poor loyalty, indeed my own household would hate me" [p. 64]. Good members of the family should be honored and rewarded effectively and surely if one wants to make the whole household temperate, well conducted and conscientious. "What is praised will soon be valued by the good, and as for the not-so-good, rewards and praises given to the good kindle in them a desire to earn the same things by similar behaviour and a similar character" [16, p. 65].

Alberti likens the father of a family to a spider constructing his web. All the threads spread out in ray, each of which, however long, has it source, its roots or birthplace at the center, from which each filament starts and moves outward. The spider is "the most industrious creature himself", and he sits in the center, remains there once his work is spun and arranged, but keeps alert and watchful that "if there is a touch on the finest and most distant thread he feels it instantly, instantly appears, and instantly takes care of the situation. Let the father of a family do likewise. Let him arrange his affairs and place them so that all look up to him alone as head, so that all are directed by him and by him attached to secure foundations. The father of the family should reside, then, in the midst of all, alert and quick to feel and to see everything, ready, wherever there is need of intervention, to provide it immediately" $[16$, p. 76$]$.

To be sure, if one knows how to rule oneself and one's family in an orderly way, one should have "the house provided for in full and abundant supply". It would be hard to convey the degree of harm which mere disorder does or, on the other hand, to explain the real value of discipline. "I don't know which is more damaging to families, the neglect of the father of the lack of discipline within the house" [16, p. 95].

\section{Concluding Note}

The strict management of the household, big or small, in whichever setting is apparently prerequisite, and the centrality of the father of the family, husband, the lord, is the key issue in both these documents, as well as public and private lives of a pater famillias, be it a lord, a Duke, or a Florentine entrepreneur. The service provided by the domestic help needs a reward, and mutual obligations are shared between masters and servants - for, if servants are not taken care of, they will "serve us poorly and not give zealous care of our concerns", as Alberti warns. The strict language of the Ordine et Ufficij and the idealistic tone of the Della Famiglia, as precepts for general social conduct, may be seen in the light of what Norbert Elias called civilizing process $[27,28]$. 


\section{Rezime}

Vojvodska palata u Urbinu se često pominje u kontekstu Kastiljoneovog Dvoranina (1528) čiji dijalog se odvija baš u ovom ambijentu kome je pripisan kvalitet mesta rođenja evropske aristokratske kulture novog veka. Za ovim spisom je usledio čitav niz traktata o poželjnom ponašanju jednog dvoranina, poput Galatea Đovanija dela Kaze (1558). Uputstva za ponašanje pojedinaca u dvorskom okruženju su starijeg datuma, ali se često bilo zbog svoje fragmentarnosti, bilo zbog pripisanom im uskom lokalnom značaju, previđaju kao značajne instance u kojima se jasno kodifikovao život u dvorskim sredinama. Jedan takav slučaj je prepis, sačuvan samo u fragmentima, uputstva za ponašanje posluge na dvoru Montefeltra u Urbinu, Ordine et officij de casa de lo Illustrissimo Signor Duca d' Urbino (Cod. Urb. lat. 1248, Biblioteca Apostolica Vaticana), kraj XV veka. Bilo da je njegov anonimni autor težio tome da stvori jedan model, idealno dvorsko domaćinstvo, ili nastojao da poboljša uslove života na samom urbinskom dvoru, ovaj spis je svakako odraz već postojeće prakse i njegova vrednost za proučavanje života na jednom renesansnom dvoru leži $\mathrm{u}$ činjenici da se autor bavi svakodnevnim obavezama trajno angažovane posluge i životom domaćinstva, a ne predstavlja traktat o dvoru i idealima dvorskog života.

\section{References}

1. Clough CH. The Duchy of Urbino in the Renaissance. London; 1981

2. Cheles L. The Studiolo of Urbino. An Iconographic Investigation. University Park. PA; 1986

3. Cieri Via C. Ipotesi di un percorso funzionale e simbolico nel Palazzo Ducale di Urbino attraverso le immagini. In: G. Cerboni Baiardi - G. Chittolini - P. Floriani (Eds), Federico di Montefeltro: Lo Stato, le arti, la cultura, Vol. 2. Roma; 1986: 47-64.

4. Clough $\mathrm{CH}$. Art as Power in the Decoration of the Study of an Italian Renaissance Prince: The Case of Federico da Montefeltro. Artibus et historiae, 1995;31(XVI):19-50.

5. Kirkbride R. Architecture and Memory. The Renaissance Studioli of Federico da Montefeltro, Columbia University Press; New York: 2008

6. Milosavljević A. Prezentacija i legitimacija vladara u dekoraciji renesansnog studiola [Presentation and legitimation of rulers in the decoration of the Renaissance studio]. Punkt; Beograd: 2013

7. Hincmar de Rheims. De Ordine Palatii, Admonitio Hincmari, Remorum Archiepiscopi. In: Prou M, editor. Bibliothèque de l' École des Hautes Études; Paris: 1884-5.

8. Eiche S, editor. Ordine et officij de casa de lo Illustrissimo Signor Duca de Urbino. Accademia Raffello; Urbino: 1999

9. Easton Law J. The Ordine et Officij: Aspects of Context and Content. In: Ordine et officij de casa de lo Illustrissimo Signor duca de Urbino. Eiche S, editor. Urbino. Accademia Raffello; 1999: 13-35.

10. Vespasiano da Bisticci. Comentario de la vita del Signore Federico, Duca d'Urbino. In: Le Vite. Vol. 1. Firenze; 1970: 355-416. 
11. Pernis MG, Schneider Adams L. Federico da Montefeltro \& Sigismondo Malatesta: The Eagle and the Elephant; New York: 1996.

12. Tuohy T. Herculean Ferrara. Ercole d'Este (1471-1505) and the Invention of a Ducal Capital. Cambridge University Press. Cambridge; 2002: $277 \mathrm{ff}$.

13. Gaye G. Carteggio inedito d'artisti dei secoli XIV, XV, e XVI. Vol. I, Doc. No. LXXXVII. Presso Giuseppe Molini. Firenze; 1839: 214-215.

14. Dennistoun J. Count Federigo's Home Administration and Court. In: Memoirs of the Dukes of Urbino, Illustrating the Arms, Arts and Literature of Italy, From 1440 to 1630. Vol. 1. London; 1851: 150-156.

15. Romano D. The Regulation of Domestic Service in Renaissance Venice. The Sixteenth Century Journal. 1999 Winter;22(4):661-677.

16. Alberti LB. The Family in Renaissance Florence. Book Three. Neu Watkins R. translation and introduction. Waveland Press. Inc. Long Grove; Illinois: 1994.

17. Alberti LB. The Ten Books of Architecture. The 1755 Leoni Edition. New York; 1986. (esp. Books V and IX)

18. Herlihy D. Mapping Households in Medieval Italy. The Catholic Historical Review. 1972 April;LVIII(1):1-24.

19. Cohen ES, Cohen TV. Family and Other Solidarities. In: Renaissance Daily Life. Greenwood Press; London: 2001. 53-70.

20. Morris L, editor. Daily Life through World History in Primary Documents. The Middle Ages and Renaissance. Greenwood Press; London: 2009. 12-51.

21. Black CF. The Family and Household. In: Early Modern Italy. A Social History. Routledge; London \& New York: 2001. 107-128.

22. Black CF. The Social Elites. In: Early Modern Italy. A Social History. Routledge; London \& New York: 2001. 129-148.

23. Boenke M. Leon Battista Alberti (1404-1472). Philosophy of Private and Public Life and of Art. In: McNeil B, Blum P, editor. Philosophers of the Renaissance. Catholic University of America Press; 2010. pp. 57-68.

24. Eiche S. Behind the Scenes at Court. In: Ordine et officij de casa de lo Illustrissimo Signor duca de Urbino. Accademia Raffello; Urbino: 1999. 45-62.

25. Johnston MD, editor. Medieval Conduct Literature. An Anthology of Vernacular Guides to Behaviour for Youths with English Translations. University of Toronto Press; Toronto: 2009.

26. Monem N, editor. Dirt. The Filthy Reality of Everyday Life. The Wellcome Trust; London: 2011.

27. Elias N. The Civilizing Process. The Sociogenetic and Psychogenetic Investigations. Blackwell Publishing Oxford, UK - Carlton; Victoria: 2000.

28. Gomes RC. The Making of a Court Society. King and Nobles in Late Medieval Portugal. Cambridge University Press; Cambridge: 2003.

Submitted: 11. 11. 2016.

Reviewed: 8. 12. 2016.

Accepted: 12. 12. 2016. 